\title{
Nephrogenic Adenoma of the Urinary Tract in Pediatric Patients: A Report of 2 Cases
}

\section{Pediatrik Hastalarda Üriner Sistemin Nefrojenik Adenomu: 2 Olgu Raporu}

\author{
(D) Eda Tokat1, (D) Serhat Gürocak1, (D) İpek Işık Gönül2, (D) Mustafa Özgür Tan1 \\ ${ }^{1}$ Gazi University Faculty of Medicine, Department of Urology, Ankara, Turkiye \\ ${ }^{2}$ Gazi University Faculty of Medicine, Department of Pathology, Ankara, Turkiye
}

\begin{abstract}
Nephrogenic adenoma (NA) is a rare, benign proliferation of glands of the urinary tract, usually occurring as a result of chronic inflammation, trauma or other similar chronic injuries to the urothelial mucosa. We aimed to share two pediatric cases diagnosed with NA in our hospital between the years 2010 and 2016. The first case was polypoid type NA of the bladder and the second case was fibromyxoid NA of the urethra.

Keywords: Nephrogenic adenoma, Genitourinary tract, Pediatric urology, Bladder, Urethra

Öz

Nefrojenik adenom (NA) üriner sistemin nadir görülen, glandüler yapılarının benign proliferasyonudur ve genellikle kronik enflamasyon, travma veya ürotelyal mukozanın benzer şekilde kronik hasarlanmasının sonucunda görülür. Biz de kliniğimizde 2010 ve 2016 yılları arasında tanı koyulan iki adet NA olgusunu paylaşmayı amaçladık. İlk olgu mesanede görülen polipoid tip NA iken, ikinci olgu üretrada görülen fibromiksoid tip NA idi. Anahtar Kelimeler: Nefrojenik adenom, Genitoüriner sistem, Pediatrik üroloji, Mesane, Üretra
\end{abstract}

\section{Introduction}

Nephrogenic adenoma (NA) is a rare benign proliferation in the urinary tract, usually occurring as a result of chronic inflammation, trauma or other similar chronic injuries to the urothelial mucosa. NA was first reported by Davis (1) in 1949 as a hamartoma of the bladder and came to be named NA after the resemblance to renal tubules was recognized. It is reported in all urothelial lined sites from the renal pelvis to urethra with the highest frequency in the urinary bladder (2). NAs rarely occur in pediatric population and are not still well studied despite the reported recurrence rate of $80 \%$ with a latency period of 4 years (3). We aimed to share two pediatric cases diagnosed with NA of the lower urinary tract in our hospital between the years 2010 and 2016.

\section{Case Presentations}

\section{Case 1}

The first patient is 2-year-old boy, who was referred from abroad with recurrent urinary tract infections (UTIs) and bilateral hydroureteronephrosis. He was operated due to pyloric stenosis on the fifth postnatal day and was followed up for epidermolysis bullosa and corneal damage. His history revealed recurrent UTIs and cloudy urine. Further investigation in another institution noted for a right duplex system and cystoscopy was uninformative. He was once hospitalized for acute renal failure. Finally, the patient was referred to our institution for recurrent UTIs, hematuria and bilateral hydronephrosis. He had intravenous pyelogram and voiding cystourethrography showing bilateral hydroureteronephrosis and absence of vesicoureteral reflux (Figures 1a, b). Remarkably, polypoid mass

Correspondence: Eda Tokat MD, Gazi University Faculty of Medicine, Department of Urology, Ankara, Turkiye

Phone: +90 3122026298 E-mail: edatokat@gmail.com ORCID-ID: orcid.org/0000-0001-6528-9149

Received: 02.05.2018 Accepted: 17.09.2018

Cite this article as: Tokat E, Gürocak S, Gönül II, Tan MÖ. Nephrogenic Adenoma of the Urinary Tract in Pediatric Patients: A Report of 2 Cases. J Urol Surg 2019;6(1):62-64.

${ }^{\circ}$ Copyright 2019 by the Association of Urological Surgery / Journal of Urological Surgery published by Galenos Publishing House. 
lesions were seen at the base of the bladder (Figure 1a). Thus, to exclude tumor, cystourethroscopy was performed and fibrin surfaced polypoid lesions covering the trigone of the bladder and including bilateral ureteral orifices were seen. The lesions were resected with meticulous coagulation to preserve ureteric orifices. Histopathological evaluation of the lesions confirmed the diagnosis of NA with staining with PAX-2 at both superficial and tubular regions (Figure 1c). After resection, in the early postoperative period, there was a marked improvement with decrease in hydrouretheronephrosis and symptoms. Follow-up after 3 months with cystoscopy was planned but the patient was lost to follow-up due to being abroad.

\section{Case 2}

The second urethral NA case is a 4-year-old boy referred for distressful dysuria and macroscopic hematuria. This was most remarkable for a urethral pathology including urethral trauma (not present in the history at all) thus, the radiologic examination consisted of an abdominal ultrasonography and

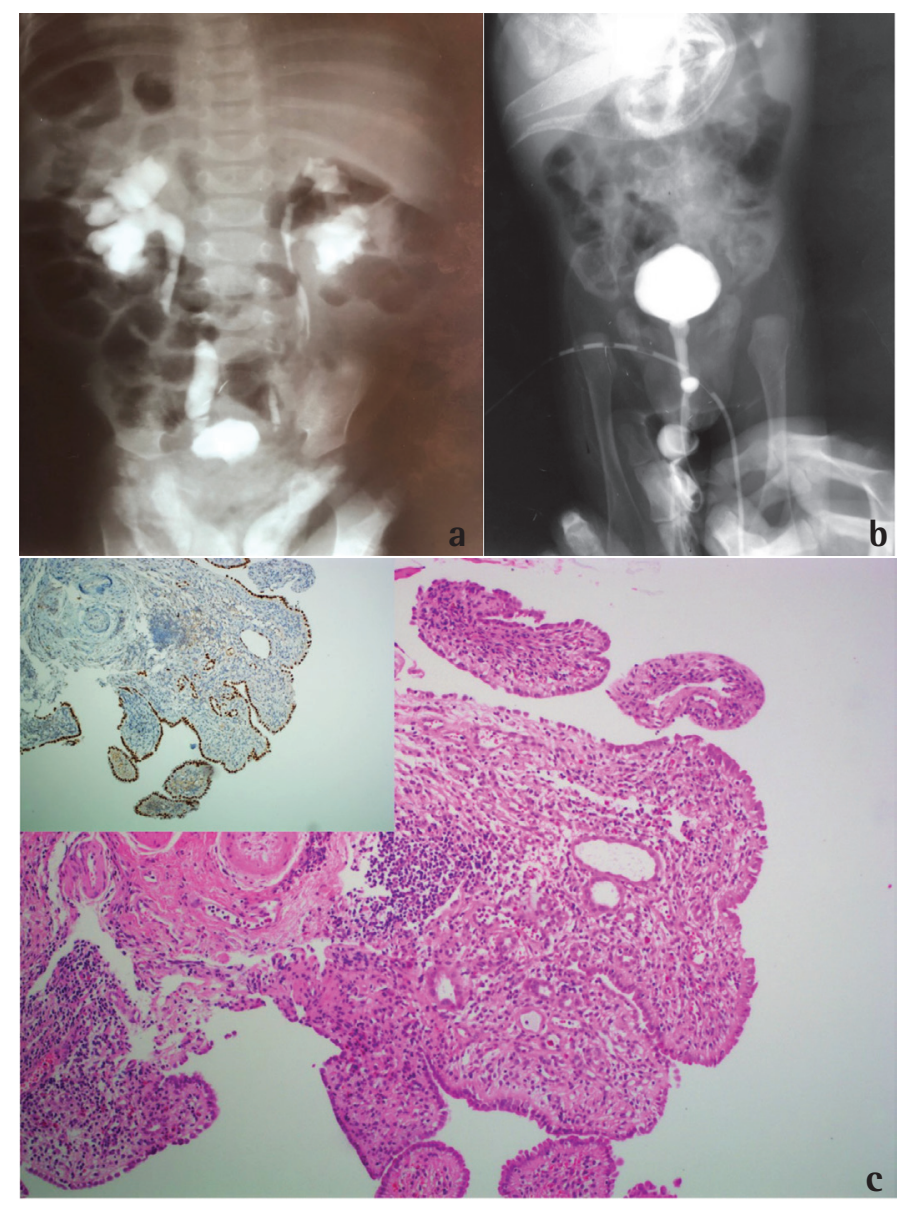

Figure 1. a) Intravenous pyelogram showing bilateral hydroureteronephrosis and polypoid mass lesions at the base of the bladder, b) voiding cystourethrography showing absence of reflux, c) polypoid type nephrogenic adenoma characterized by urothelial lining with PAX-8 (+) (inset) cuboidal cells (inset: Tubules easily recognized by PAX-8 immunohistochemistry) a plain abdominal X-ray including the penis to exclude stone disease. Laboratory tests (only hematuria, no infection) and radiological examinations (completely normal urinary tract) failed to confirm a specific diagnosis, thus, we carried out cystoscopy to examine the urethra and the bladder. There was mild urethral stenosis but required meatoplasty for cystoscopy. At urethroscopy, a 3-4 mm small polypoid lesion was seen in the bulbar urethra. The appearance and location were accepted as unusual that at that time thought to be related with a trauma or probable previous urethral catheterization (there was no history for both however). The lesion was completely removed by cold cut biopsy forceps and the base and circumference area were fulgurated using holmium laser meticulously to prevent damage to the urethra. The bladder mucosa was normal except mild trabeculation. Histological examination of the polyp confirmed the diagnosis of fibromyxoid NA because of pseudovascular tubular structures that were immunostained with ceratine 7, panceratine, PAX-2 and PAX-8 (Figure 2). After treatment, there was marked regression of the symptoms, mainly hematuria. Confident with the diagnosis, we preferred to follow-up the patient deferring diagnostic cystoscopy as late as possible to avoid further trauma to the urethra considering the casual effect on the lesion for a period of 2 years.

Informed consent was obtained from both patients.

\section{Discussion}

NA is a rare entity in adults and children. While it is 3 times more frequent in males than in females, the ratio is thought to be reversed in children. It is more frequently observed in the bladder than in the urethra with the occurrence rate of 15\% (4).

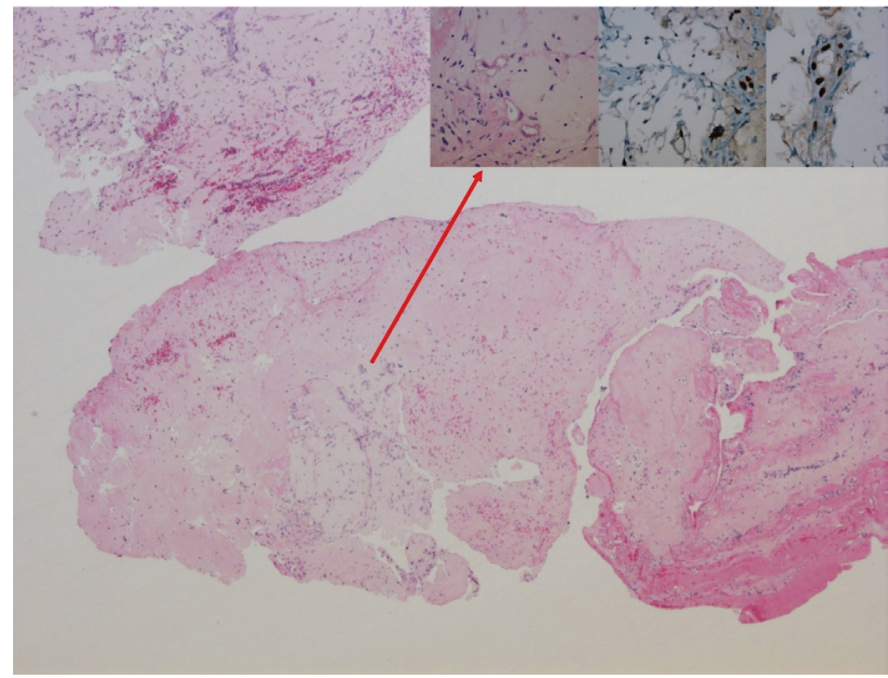

Figure 2. PAX-8 (+) (inset) spindle cells and rare tubular structures embedded in an abundant fibromyxoid stroma in fibromyxoid type nephrogenic adenoma (hematoxylin and eozin, 40x; inset: Tubules easily recognized by PAX-8 immunohistochemistry) 
There are numerous diseases that could result in macroscopic hematuria in children and the majority is related to nephrologic causes, namely immunoglobulin A nephropathy. The common causes for non-glomerular gross hematuria could be hypercalciuria (stones), urethrorrhagia (trauma) and hemorrhagic cystitis (infection). Neoplastic lesions are relatively uncommon, but must be excluded.

Accordingly, our second NA case represents a very rare cause of gross hematuria. Similarly, physical examination and radiological evaluation rarely yield informative evidence for diagnosis. Kumar et al. (5) have also reported that children with gross hematuria with normal radiographic results required cystoscopy. Accordingly, we undertook cystoscopy in our cases to diagnose and also made profit of treatment. In fact, NA has a non-specific endoscopic appearance and may mimic tumors, thus, histopathological examination of resected or biopsy specimens is essential for the diagnosis.

The most common histological description of NA is presence of tubular structures resembling mesonephric tubules (6). Papillary projections may also be seen. The small tubules are often surrounded by a thickened hyalinised basement membrane without a desmoplastic stromal response $(2,3,7)$. The main differential diagnoses include prostatic adenocarcinoma and clear cell adenocarcinoma of the urethra in adults and rhabdomyosarcoma and transitional cell carcinoma in children $(1,4,7)$. Certain immunohistological markers, such as PAX-2 or PAX-8, may help to differentiate NA from urothelial carcinomas or prostatic adenocarcinoma but expression of PAX-2 and PAX8 is also seen in clear cell adenocarcinoma and may be hard to discriminate from NA (7). An experienced pathologist can make decision with the help of histological key features. Positive reaction with panceratine antibody, vimentin antibody and cytoceratine indicates the mesonephrogenic origin (8). Our both cases were tubular structured and the bladder case was PAX2-positive and urethral case was immune-stained additionally with PAX-8, ceratine 7 and panceratine. In addition, urethral NA was a rare type that can mimic mucinous adenocarcinoma (9).

The lesion is usually solitary but can be multifocal (4); in our urethral case, it was an example of a solitary lesion and in the bladder case, it was a multifocal lesion. History of UTI, inflammation, trauma or recent surgery, calculi or catheterization in most cases or immunosuppression after transplantation are possible causes of NA. Our bladder case had a history of recurrent UTI and recent repetitive cystoscopy but, on the other hand, urethral case did not provide the condition of chronic injuries to the urothelial mucosa. By this way, every gross hematuria in a child, not associated with a diagnosis, requires cystoscopy.
There is a consensus that NA is a benign lesion. The main treatment is transurethral resection and fulguration of the tumor base. However, the recurrence rate has been reported to be as high as 37\% (8). Because of this predisposition, a followup with cystoscopy is recommended (4). Also repeating surgeries are known to be a reason of trauma to the urothelial mucosa and we think about not to perform cystoscopy while the patient is asymptomatic to avoid urethral injury.

\section{Ethics}

Informed Consent: Informed consent was obtained from both patients.

Peer-review: Externally peer-reviewed.

\section{Authorship Contributions}

Concept: E.T., M.Ö.T., Design: E.T., M.Ö.T., Data Collection or Processing: E.T., M.Ö.T., I..I.G., Analysis or Interpretation: S.G., I.I.G., Literature Search: E.T., Writing: E.T.

Conflict of Interest: No conflict of interest was declared by the authors.

Financial Disclosure: The authors declared that this study received no financial support.

\section{References}

1. Davis TA. Hamartoma of the urinary bladder. Northwest Med 1949;48:182185.

2. Ford TF, Watson GM, Cameron KM. Adenomatous metaplasia (nephrogenic adenoma) of urothelium: an analysis of 70 cases. Br J Urol 1985;57:427433.

3. Kao CS, Kum JB, Fan R, Grignon DJ, Eble JN, Idrees MT. Nephrogenic adenomas in pediatric patients: a morphologic and immunohistochemical study of 21 cases. Pediatr Dev Pathol 2013;16:80-85.

4. de Buys Roessingh AS, Laurini RN, Meyrat BJ. Nephrogenic adenoma of the urethra: an unusual cause of hematuria in the child. J Pediatr Surg 2003;38:8-9.

5. Kumar GK, Malcomson R, Chandran H. Nephrogenic adenoma of the urethra presenting as hematuria. Indian J Surg 2014;76:228-229.

6. Crook TJ, Mead Z, Vadgama B, Malone PS. A case series of nephrogenic adenoma of the urethra and bladder in children: review of this rare diagnosis, its natural history and management, with reference to the literature. J Pediatr Urol 2006;2:323-328.

7. Alexiev BA, LeVea CM. Nephrogenic adenoma of the urinary tract: a review. Int J Surg Pathol 2012;20:123-131.

8. Steffens J, Seitz G, Wernert N, Alloussi S, Ziegler M. Nephrogenic adenoma of the bladder in a child--immunohistochemical and lectinhistochemical investigations. Eur Urol 1990;18:64-67.

9. Hansel DE, Nadasdy T, Epstein Jl. Fibromyxoid nephrogenic adenoma: a newly recognized variant mimicking mucinous adenocarcinoma. Am J Surg Pathol 2007;31:1231-1237. 